Yohko Orito, Kiyoshi Murata and Yasunori Fukuta:

\title{
Do online privacy policies and seals affect corporate trustworthiness and reputation?
}

\begin{abstract}
:
In this study, we attempt to examine the effectiveness of online privacy policies and privacy seals/security icons on corporate trustworthiness and reputation management, and to clarify how young Japanese people evaluate the trustworthiness of $\mathrm{B}$ to $\mathrm{C}$ e-business sites in terms of personal information handling. The survey results indicate that posting online privacy policies and/or privacy seals/security icons by $\mathrm{B}$ to $\mathrm{C}$ e-businesses does not work for creating trust in business organisations by consumers actively. Instead, existing good name recognition and/or general reputation can engender trust and, increasingly, better their reputation in terms of personal information use and protection.
\end{abstract}

\section{Agenda:}

Introduction

Overview of the survey

The survey results

Online privacy policies. 55

Security technologies, privacy seals and security icons

The evaluation standards for providing personal information 58

Self-awareness and self-responsibility in terms of misuse of personal information and associated damage 60

Implications of the survey results for B to C e-business companies' trustworthiness and reputation management

Conclusions

\section{Authors:}

Dr. Yohko Orito

- $\quad$ Faculty of Law and Letters, Ehime University, 3 Bunkyo-cho, Matsuyama, Ehime 790-8577, Japan

- $\quad$ orito@ll.ehime-u.ac.jp

- Relevant publications:

1. Adams, A. A., Murata, K., Orito, Y. and Parslow, P.: Emerging Social Norms in the UK and Japan on Privacy and Revelation in SNS, International Review of Information Ethics, 16, pp. 1821,2011. http://www.i-r-i-e.net/inhalt/016/adams-etal.pdf

2. Orito, Y.: The Counter-Control Revolution: "Silent Control" of Individuals through Dataveillance Systems, Journal of Information,Communication and Ethics in Society, 9 (1), pp. 5-19,2010. http://dx.doi.org/10.1108/14779961111123197.

3. Adams, A. A., Murata, K. and Orito, Y.: The Japanese Sense of Information Privacy, AI \& Society, 24 (4), pp. 327-341, 2009. http://dx.doi.org/10.1007/s00146-009-0228-z 
Prof. Kiyoshi Murata

- Centre for Business Information Ethics, Meiji University, 1-1 Kanda Surugadai, Chiyoda, Tokyo 1018301, Japan

- kmurata@kisc.meiji.ac.jp, + 8133296 2165, www.kisc.meiji.ac.jp/ ethicj

- Relevant publications:

4. Murata, K., Orito, Y. and Fukuta, Y.: Japanese Youngsters' Social Attitude towards Online Privacy, forthcoming to Journal of Law, Information and Society.

5. Murata, K. and Orito, Y.: Rethinking the Concept of the Right to Information Privacy: A Japanese Perspective, Journal of Information, Communication and Ethics in Society, 6 (3), pp. 233-245, 2008. http://dx.doi.org/10.1108/14779960810916237

6. Orito, Y. and Murata, K.: Socio-cultural Analysis of Personal Information Leakage in Japan, Journal of Information, Communication and Ethics in Society, 6 (2), pp. 161-171, 2008. http://dx.doi.org/10.1108/14779960810888365

Associate Prof. Yasunori Fukuta

- School of Commerce, Meiji University, 1-1 Kanda Surugadai, Chiyoda, Tokyo 101-8301, Japan

- yasufkt@kisc.meiii.ac.jp +81332962624

- Relevant publications:

7. Murata, K., Orito, Y. and Fukuta, Y.: Japanese Youngsters' Social Attitude towards Online Privacy, forthcoming to Journal of Law, Information and Society.

8. Orito, Y., Kim, E., Fukuta, Y. and Murata, K.: Online Privacy and Culture: A Comparative Study between Japan and Korea, Proceedings of ETHICOMP 2011, pp. 338-346, 2011.

9. Orito, Y., Murata, K., Fukuta, Y., McRobb, S. and Adams, A. A.: Online Privacy and Culture: Evidence from Japan, Proceedings of ETHICOMP 2008, pp. 615-622, 2008. 


\section{Introduction}

Today, for general consumers living in developed countries, online shopping behaviour has become common. Given this situation, it is alleged that one of the best ways for $\mathrm{B}$ to $\mathrm{C}$ e-business organisations to preserve their high trustworthiness and good reputation regarding personal information handling and privacy protection among their customers is to post a privacy or personal information protection policy on their website to allow customers to understand how they appropriately handle personal information and address privacy issues. Another way is to put a third-party certified privacy seal and/or security icon, such as TRUSTe or BBB, on their website. In fact, a large majority of $B$ to $C$ e-business organisations do post their privacy or personal information protection policies and privacy seals and/or security icons on their online shopping sites.

As in other developed countries, in Japan, personal information protection by private organisations has been the subject of legislation. The Act on the Protection of Personal Information (APPI; Act No. 57 of 2003) went into effect in April 2005. Enforcement of this law has encouraged Japanese $B$ to $C$ e-business organisations to put their privacy or personal information protection policies, consistent with APPI, and personal information protection guidelines provided by the relevant ministries, agencies, and municipalities based on APPI, on their websites. Additionally, many Japanese business organisations have acquired the "Privacy Mark" and put it on the front page of their websites. This refers to a Japanese privacy seal scheme run by the Japan Information Processing Development Corporation (JIPDEC), an extra-governmental body of the Ministry of Economy, Trade, and Industry (METI). The Next Generation Electronic Commerce Promotion Council of Japan (ECOM: this extra-governmental body was dissolved at the end of FY 2010 and merged into JIPDEC) emphasised the importance of e-business organisations' providing a link to a well-organised and appropriately-described privacy or personal information protection policy and putting the Privacy Mark on the front page of their websites to affirm their trustworthiness and reputation to customers (ECOM, 2008).

However, there are different viewpoints on the effectiveness of online privacy policies and seals on promoting corporate trustworthiness and reputation management. For example, Pollach (2007) suggested that online privacy policies have been drafted by business organisations with the threat of privacy litigation in mind, rather than as a commitment to the appropriate handling of personal information. On the other hand, although nobody would dispute the importance of online privacy protection, many online consumers may not, in fact, read long privacy policy statements put on an online shopping site and not give much attention to a privacy seal posted on a website when they provide personal information to a site to purchase something from it. Indeed, if this is the case, do online privacy policies and seals affect consumer attitudes to corporate trustworthiness and reputation at all?

Given this background, analysing the results of questionnaire and interview surveys conducted in 2013, and taking the authors' analyses of previous surveys conducted in 2008 and 2011 (Orito et al., 2008; 2011; Murata et al., 2013) into account, this study attempts to examine the effectiveness of online privacy policies and privacy seals/security icons on corporate trustworthiness and reputation management, and to clarify how Japanese people evaluate the trustworthiness of $\mathrm{B}$ to $\mathrm{C}$ e-business sites in terms of personal information handling and any relationship between the evaluation and corporate reputation.

In light of the survey results, it appears that posting online privacy policies does not work in engendering trust among consumers. Instead, existing good name recognition and/or general reputation of the business organisation that operates a B to C e-business site can engender trust and enhance a company's reputation in terms of personal information use and protection. That is, the halo effect and the Matthew effect (Merton, 1968) can be observed with regard to corporate trustworthiness and reputation when it comes to personal information handling. 


\section{Overview of the survey}

The questionnaire survey was conducted in May 2013 using the online questionnaire website. The respondents were university students at the School of Commerce of Meiji University in Tokyo, the capital city of Japan, and at the Faculty of Law and Letters of Ehime University, in the city of Matsuyama. Of the 604 survey responses (Meiji University: 340, Ehime University: 264), 600 responses were valid (336 and 264, respectively). The survey's intended population was similar to that in our questionnaire surveys conducted in 2008 and 2011. The respondents had the option of providing their real name or student number (identification number), so that follow-up interviews with students who provided their name or student number could be done. In fact, 28 respondents (Meiji University 26, Ehime University 2) were interviewed to ask follow-up questions about outcomes and to discuss certain controversial or contradictory outcomes.

Respondent attributes are shown in Table 1, and the complete questionnaire sheet is provided in the Appendix. The questionnaire's title was "Online Shopping Survey 2013", and at the start of the questionnaire it included an explicit statement - "The aim of this survey is to analyse online shopping behaviour" - to avoid priming. Tendencies of and relationships between responses to the questionnaire were examined through statistical tests, including Pearson's chi-squared test and Fisher's exact test. The proportion of respondents who had online shopping experience had increased from $71.7 \%$ in 2008 to $78.3 \%$ in 2013 . Additionally, the proportion of respondents who had provided personal information to any website had increased from $83.1 \%$ in 2011 to $94.1 \%$ in 2013. Over three-quarters of those who responded in the 2013 survey had bought something online and had provided personal information to websites.

Table 1. Respondent attributes

\begin{tabular}{|c|c|c|c|c|c|c|}
\hline $\begin{array}{l}\text { Age } \\
\text { The number of respondents (\%) }\end{array}$ & $\begin{array}{c}18 \\
183 \\
(30.5)\end{array}$ & $\begin{array}{c}19 \\
82 \\
(13.7)\end{array}$ & $\begin{array}{c}20 \\
163 \\
(27.1)\end{array}$ & $\begin{array}{c}21 \\
104 \\
(17.3)\end{array}$ & $\begin{array}{c}22 \\
45 \\
(7.5)\end{array}$ & $\begin{array}{c}23+ \\
23 \\
(3.8)\end{array}$ \\
\hline Gender (\%) & \multicolumn{3}{|c|}{ Male $352(58.7)$} & \multicolumn{3}{|c|}{ Female $245(40.8)$} \\
\hline $\begin{array}{l}\text { Q5. Have you bought something on the Web? } \\
(\%)\end{array}$ & \multicolumn{3}{|c|}{ Yes $470(78.3)$} & \multicolumn{3}{|c|}{ No $130(21.7)$} \\
\hline $\begin{array}{l}\text { Q6: Have you provided your personal infor- } \\
\text { mation including your name, residential ad- } \\
\text { dress, phone number and credit-card number to } \\
\text { any website? }(\%)\end{array}$ & \multicolumn{3}{|c|}{$\begin{array}{c}\text { Yes } 443 \\
(94.1)\end{array}$} & \multicolumn{3}{|c|}{$\begin{array}{c}\text { No } 28 \\
(6.0)\end{array}$} \\
\hline
\end{tabular}

\section{The survey results}

\section{Online privacy policies}

From the survey results, more than $80 \%$ of respondents knew of the existence of online privacy policies $(81.2 \%)$. This high recognition rate of online privacy policies was consistently observed in the two previous surveys, conducted in 2008 and 2011 (83.9\% and $72.6 \%$, respectively). Moreover, the proportion of respondents who considered an online privacy policy as an important element for their online shopping was $88.9 \%$, and a similar high evaluation of the importance of online privacy policies was seen in the 2008 and 2011 surveys ( $74.2 \%$ and $96.8 \%$, respectively).

On the other hand, the results of the survey conducted in 2013, as well as previous survey results, continue to indicate that more than half of the respondents who acknowledged the importance of online privacy policies when they purchased something online did not actually read the policies frequently. Table 2 shows a crosstabulation between Q8 and Q9. As a result of a chi-squared test, it was confirmed statistically that the respondents who accepted the importance of online privacy policies for their online shopping tended to read the online privacy policies, as compared to respondents who did not regard online privacy policies as an important 
element (chi-squared $(1)=25.997, p<.01)^{106}$ who seldom read them, if at all. However, more than half of the respondents who acknowledged the importance of the policies did not actually read them very frequently. Consequently, among the respondents who considered an online privacy policy to be very important or important, the proportion of respondents who answered, "I seldom read online privacy policies," was higher than the proportion of respondents who answered, "I read online privacy policies occasionally." and "I read online privacy policies frequently."

Moreover, it seems that their recognition of the importance of online privacy policies is not necessarily relevant to their practical concerns about online privacy policies. From the chi-squared test results, it was confirmed statistically that the respondents who accepted the importance of online privacy policies for their online shopping tended to worry about compliance with the policies, as compared to those who did not regard the policies as an important element (chi-squared $(1)=13.456, p<.01)^{107}$. However, this result does not mean that the many respondents who recognised the importance of the policies also paid attention to companies' compliance with them. As Table 3 shows, it is notable that more than half of these respondents answered that they rarely worried or did not worry about companies' compliance with online privacy policies. That is, even among the respondents who recognised the importance of the policies, the majority of them did not worry about whether online shopping companies actually complied with their online privacy policies.

These tendencies were the same in terms of the respondents' sense of trust in the companies' compliance with their online privacy policies. The survey results show the tendency that over three-quarters of the respondents who answered Q11 believed that companies did comply with their privacy policies (Table 4). Although the proportion of respondents who do not read online privacy policies was highest, many of them seemed to believe that many companies did comply with their online privacy policies (Table 5). Thus, regardless of their recognition of the importance of online privacy policies, or whether they had read online privacy policies, it seems that the majority of respondents believed companies did comply with online privacy policies without any reasonable ground or clear evidence for it. It is a matter of particular interest that more respondents who considered online privacy policies to be important had optimistic attitudes with regard to companies' compliance with online privacy policies.

Table 2. Important, but unread online privacy policies

\begin{tabular}{|c|c|c|c|c|c|c|}
\hline & \multicolumn{4}{|c|}{ Q9 : Do you read a privacy policy when you purchase something online? } & \multirow[b]{2}{*}{ Total } \\
\hline & & $\begin{array}{c}\text { I read them fre- } \\
\text { quently }\end{array}$ & $\begin{array}{l}\text { I read them oc- } \\
\text { casionally }\end{array}$ & $\begin{array}{c}\text { I seldom read } \\
\text { them }\end{array}$ & $\begin{array}{c}\begin{array}{c}\text { I have not read } \\
\text { them at all }\end{array} \\
\end{array}$ & \\
\hline \multirow{4}{*}{$\begin{array}{l}\text { Q8: Is a privacy } \\
\text { policy an im- } \\
\text { portant element } \\
\text { for your online } \\
\text { shopping? }\end{array}$} & $\begin{array}{l}\text { Very im- } \\
\text { portant }\end{array}$ & 20 & 55 & 69 & 18 & 162 \\
\hline & Important & 3 & 66 & 87 & 17 & 173 \\
\hline & $\begin{array}{l}\text { Not so im- } \\
\text { portant }\end{array}$ & 0 & 1 & 32 & 7 & 40 \\
\hline & $\begin{array}{c}\text { Not important } \\
\text { at all }\end{array}$ & 0 & 0 & 0 & 2 & 2 \\
\hline & Total & 23 & 122 & 188 & 44 & 377 \\
\hline
\end{tabular}

\footnotetext{
${ }^{106}$ Because of the skewed data distribution, we applied the chi-squared test to a two-by-two matrix, which consisted of two rows related to Q8 (one row includes "very important" and "important" and the other includes "not important" and "not important at all") and two columns related to Q9 (one column includes "read frequently" and "read occasionally" and the other includes "seldom read" and "never read").

${ }^{107}$ For the same reason which is described in the previous footnote, we applied the chi-squared test to a two-by-two matrix, which consisted of two rows related to Q8 (one row includes "very important" and "important" and the other includes "not important" and "not important at all") and two columns related to Q10 (one column includes "usually worry" and "sometimes worry" and the other includes "rarely worry" and "have not worried").
} 
Table 3. Acknowledge as important but appear unconcerned about online privacy policies

\begin{tabular}{|c|c|c|c|c|c|c|}
\hline & \multicolumn{4}{|c|}{$\begin{array}{l}\text { Q10: Have you worried about whether online shopping companies abide } \\
\text { by their online privacy policies or not? }\end{array}$} & \multirow[b]{2}{*}{ Total } \\
\hline & & $\begin{array}{l}\text { I usually worry } \\
\text { about this }\end{array}$ & $\begin{array}{l}\text { I sometimes } \\
\text { worry about this }\end{array}$ & $\begin{array}{l}\text { I rarely worry } \\
\text { about this }\end{array}$ & $\begin{array}{l}\text { I have not worried } \\
\text { about this at all }\end{array}$ & \\
\hline \multirow{4}{*}{$\begin{array}{l}\text { Q8:Is a privacy } \\
\text { policy an im- } \\
\text { portant element } \\
\text { for your online } \\
\text { shopping? }\end{array}$} & $\begin{array}{l}\text { Very im- } \\
\text { portant }\end{array}$ & 23 & 77 & 54 & 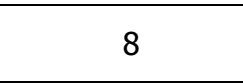 & 162 \\
\hline & Important & 7 & 57 & 97 & 12 & 173 \\
\hline & $\begin{array}{l}\text { Not so im- } \\
\text { portant }\end{array}$ & 0 & 8 & 29 & 3 & 40 \\
\hline & $\begin{array}{l}\text { Not important } \\
\text { at all }\end{array}$ & 0 & 0 & 0 & 2 & 2 \\
\hline & Total & 30 & 142 & 180 & 25 & 377 \\
\hline
\end{tabular}

Table 4. Important, and reliable company compliance with online privacy policies

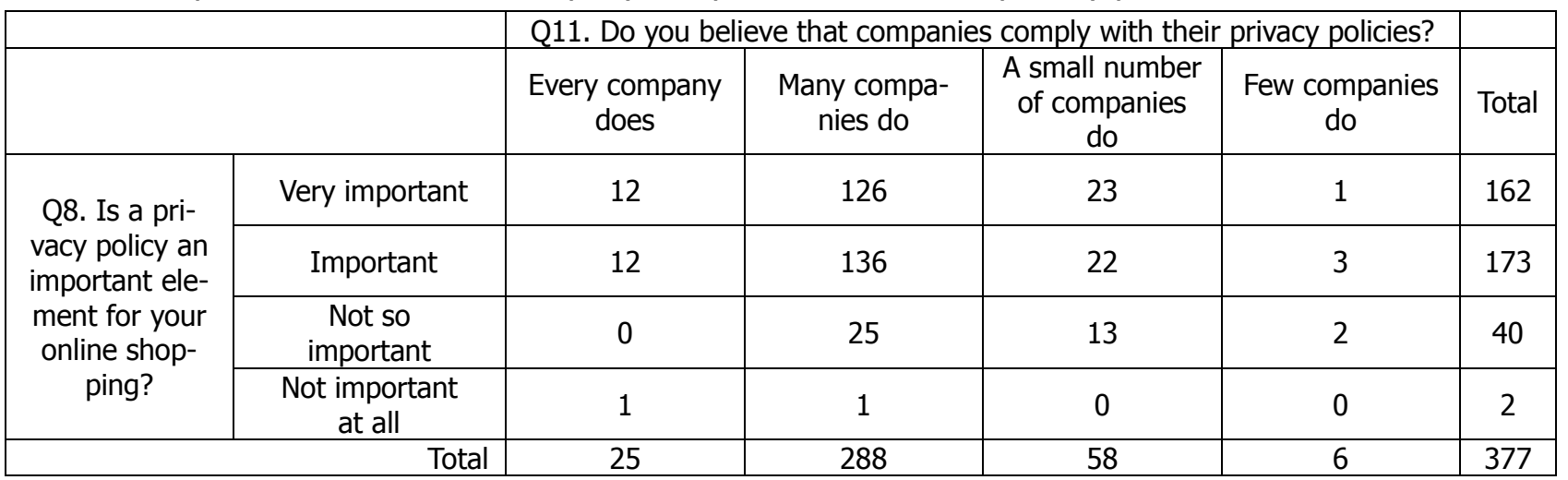

Table 5. Unread but reliable company compliance with online privacy policies

\begin{tabular}{|c|c|c|c|c|c|c|}
\hline & & \multicolumn{4}{|c|}{$\begin{array}{l}\text { Q11: Do you believe that companies comply with their privacy poli- } \\
\text { cies? }\end{array}$} & \multirow[b]{2}{*}{ Total } \\
\hline & & $\begin{array}{l}\text { Every com- } \\
\text { pany does }\end{array}$ & $\begin{array}{l}\text { Many compa- } \\
\text { nies do }\end{array}$ & $\begin{array}{l}\text { A small num- } \\
\text { ber of compa- } \\
\text { nies do }\end{array}$ & $\begin{array}{c}\text { Few companies } \\
\text { do }\end{array}$ & \\
\hline \multirow{4}{*}{$\begin{array}{l}\text { Q9:Do you } \\
\text { read a privacy } \\
\text { policy when } \\
\text { you purchase } \\
\text { something } \\
\text { online? }\end{array}$} & $\begin{array}{l}\text { I read them fre- } \\
\text { quently }\end{array}$ & 2 & 16 & 5 & 0 & 23 \\
\hline & $\begin{array}{l}\text { I read them occasi- } \\
\text { onally }\end{array}$ & 8 & 99 & 14 & 1 & 122 \\
\hline & $\begin{array}{l}\text { I seldom } \\
\text { read them }\end{array}$ & 12 & 144 & 28 & 4 & 188 \\
\hline & $\begin{array}{l}\text { I have not read } \\
\text { them at all }\end{array}$ & 3 & 29 & 11 & 1 & 44 \\
\hline & Total & 25 & 288 & 58 & 6 & 377 \\
\hline
\end{tabular}


Why do the respondents not read privacy policies but yet they believe that companies comply with online privacy policies when they shop online? To help understand this, follow-up interviews were conducted with the 28 respondents, and several common factors could be found to explain why the respondents do not read online privacy policies. Most of them mentioned that almost all online privacy policies had long statements, which were not designed to facilitate consumer understanding, and the policies were simply not easy to understand. That is, for consumers, reading an online privacy policy is bothersome. Additionally, several interviewees reported that many policies had similar content and, therefore, they were not particularly motivated to read and/or understand the policies. Some interviewees responded that it was better to have an online privacy policy, rather than no policy, and one of them said that, "If some misuse of personal information is occurring, it should be reported; if it is not happening, it is safe." Unless cases of misuse of personal information or data leakage are reported, many customers may not care about the issue. It also seems that many companies do not make active efforts to develop consumer-friendly online privacy policies.

\section{Security technologies, privacy seals and security icons}

Q23 asked respondents about their recognition of encryption technology and Q24 asked them about the meaning of the padlock icon, which is shown in the browser when they visit online shopping sites. The proportion of the respondents who understood the encryption of personal information during transmission was over half (55.9\%). Conversely, the proportion of respondents who understood the meaning of the padlock icon was considerably below half (32.7\%) and those who answered, "I have seen this icon, but I don't know what it represents," accounted for $50.2 \%$ of the respondents. It appears that the respondents' recognition of encryption technologies was not very high.

Additionally, many respondents did not understand the meaning of privacy seals and security icons (Table 6). The recognition of TRUSTe, Thawte, and BBB remained at a low level compared with the recognition of the Privacy Mark and VeriSign. However, the proportion of respondents who answered, "I know the meaning of the Privacy Mark," was $1.9 \%$, and VeriSign was $1.1 \%$ in 2008, and the proportions of respondents who answered, "I have seen this icon, but I don't know what it represents," were $15.4 \%$ and $36.5 \%$, respectively, in 2008. Thus, when mention was made of the Privacy Mark and VeriSign, the percentage of respondents who acknowledged these two seals had increased, but the majority of respondents seemed not to have a clear understanding of their meanings. When we asked one interviewee about this point, the interviewee who did not know the Privacy Mark said, "I think this is such a waste, if it requires the companies to pay the expensive cost of obtaining a Privacy Mark, because many of us don't know what it means," when this interviewee was informed of the meaning and process and cost for obtaining the Privacy Mark by one of the authors.

Table 6. Recognition of privacy seals/security icons

\begin{tabular}{|l|c|c|c|c|c|}
\hline $\begin{array}{l}\text { Do you recognise the following seal/icon? } \\
(\%)\end{array}$ & $\begin{array}{c}\text { Q25:Privacy } \\
\text { Mark }\end{array}$ & Q26:TRUSTe & Q27:Thawte & Q28:BBB & Q29:VeriSign \\
\hline Yes, I know what this seal/icon represents & $31(7.1)$ & $10(2.3)$ & $6(1.4)$ & $6(1.4)$ & $49(11.2)$ \\
\hline $\begin{array}{l}\text { I have seen this seal/icon, but I don't know } \\
\text { what it represents }\end{array}$ & $93(21.2)$ & $31(7.1)$ & $39(8.9)$ & $42(9.6)$ & $159(36.2)$ \\
\hline I don't know this seal/icon at all & $315(71.8)$ & $398(90.7)$ & $394(89.7)$ & $391(89.1)$ & $231(52.6)$ \\
\hline
\end{tabular}

\section{The evaluation standards for providing personal information}

Q18 asks, "What characteristics does a website have to which you don't want to provide your personal information?" and Q19 asks, "What characteristics does a website have to which you feel safe to provide your personal information?" Respondents can select multiple answers to each question. The results of Q18 and Q19 
are provided in Tables 7 and 8, respectively. It is easy to see that many respondents used name recognition of the websites or their operators rather than the implementation of privacy protection schemes, as a standard to evaluate the trustworthiness of $\mathrm{B}$ to $\mathrm{C}$-commerce sites in terms of personal information use and protection. Additionally, over half of the respondents did not want to provide information to websites that have suspect web designs and too many advertisements; such websites may have a disadvantage in some cases, even if they earnestly work to establish appropriate privacy protection schemes.

Table 7. Characteristics of websites where respondents did not want to provide personal information

\begin{tabular}{|c|c|}
\hline Answers & Number (\%) \\
\hline Websites that have a low profile or are operated by low-profile companies & $328(74.0)$ \\
\hline Websites that require too much personal information & $287(64.8)$ \\
\hline Websites with untrustworthy reputations & $272(61.4)$ \\
\hline Websites I do not want people to know I access & $263(59.4)$ \\
\hline Websites that have suspect designs and too many advertisements & $248(56.0)$ \\
\hline Websites that provide suspect goods and services & $242(54.6)$ \\
\hline $\begin{array}{r}\text { Websites that seem to fail to show well-organised privacy policies, personal information } \\
\text { protection schemes, and security }\end{array}$ & $239(54.0)$ \\
\hline Websites that can be accessed by the general public online & $218(49.2)$ \\
\hline Websites that require a money transaction & $99(22.3)$ \\
\hline Websites that provide free services & 88 (19.9.) \\
\hline Any websites & $75(16.9)$ \\
\hline I have no idea & $5(1.1)$ \\
\hline Other & $0(0)$ \\
\hline
\end{tabular}

Table 8. Characteristics of websites where respondents felt safe in providing personal information

\begin{tabular}{|c|c|}
\hline Answers & Number $(\%)$ \\
\hline Websites with a high profile and high traffic, or having many users & $284(64.3)$ \\
\hline $\begin{array}{r}\text { Websites that seem to have well-organised privacy policies and personal information protection } \\
\text { schemes }\end{array}$ & $247(55.9)$ \\
\hline Websites that seem to maintain technological security & $204(46.2)$ \\
\hline Websites that I and/or my friends have used & $130(29.4)$ \\
\hline Websites whose reputation information provided by a third party is accessible & $117(26.5)$ \\
\hline Websites that have restricted access & $107(24.2)$ \\
\hline Online shopping websites and auction websites & $91(20.6)$ \\
\hline $\begin{array}{cc}\text { Recruiting websites } \\
\end{array}$ & $88(19.9)$ \\
\hline Websites that allow users to communicate directly with operators of the websites & $69(15.6)$ \\
\hline Websites operated by my acquaintances & $44(10.0)$ \\
\hline Websites that have a preferable web design & $9(2.0)$ \\
\hline Nothing & $35(7.9)$ \\
\hline I have no idea & $15(3.4)$ \\
\hline Other & $0(0)$ \\
\hline
\end{tabular}

If the most important factors for cultivating consumer trust in online businesses are name recognition and the reputation of websites and/or their operators, it would seem that the efforts of companies in terms of online privacy protection alone are not rewarded. Are there any successful measures that improve consumer recognition of company efforts on privacy protection? To examine these issues, a question that asked about the level of an online privacy policy was included in the questionnaire sheet. Q12 asked, "If you purchase products or services online that are similar in price, would you prefer to purchase them on a website that provides a highly advanced online privacy policy as opposed to a website that provides a lower level online privacy policy?" The answers are provided in Table 9 . Over $90 \%$ of respondents showed positive attitudes towards a highly advanced online privacy policy. 
Table 9. Differences in level of an online privacy policy

\begin{tabular}{|l|c|c|c|c|}
\hline $\begin{array}{l}\text { Q12: If you purchase products or services online that } \\
\text { are similar in price, would you prefer to purchase } \\
\text { them on a website that provides a highly advanced }\end{array}$ & $\begin{array}{c}\text { Yes, I 'd } \\
\text { like to, very } \\
\text { much }\end{array}$ & $\begin{array}{c}\text { Yes, if any- } \\
\text { thing }\end{array}$ & $\begin{array}{c}\text { I'm not } \\
\text { quite sure } \\
\text { on that } \\
\text { point }\end{array}$ & $\begin{array}{c}\text { No, I would } \\
\text { not }\end{array}$ \\
\cline { 2 - 5 } $\begin{array}{l}\text { sentences, with icons and pictures), as opposed to a } \\
\text { website that provides a lower level online privacy } \\
\text { policy? (\%) }\end{array}$ & $188(50.1)$ & $154(41.1)$ & $30(8.0)$ & $3(0.8)$ \\
\hline
\end{tabular}

In this regard, it is important to examine in detail respondents' attitudes towards online privacy protection schemes, and if they are willing to accept the development of high-level online privacy policies. Q13 was designed to investigate these points; it provided interesting results about which conditions can lead to higher interest by respondents in a company's implementation of appropriate schemes for the protection of privacy when they purchase something online (Table 10). According to the results, to some extent, respondents paid attention to the kind of personal information required from the websites; thus, the qualitative aspect of the personal information they would need to provide seems to be an important factor. Additionally, because $47.3 \%$ of respondents selected high-priced goods and services, they seem to have concerns about the protection of privacy, taking cost-benefit performance into account. Further examination is necessary to analyse these issues in this context.

Table 10. Extra attention to online privacy protection

\begin{tabular}{|r|c|}
\hline $\begin{array}{l}\text { Q13: If you purchase something online, under what circumstances is it to be } \\
\text { noted whether the online shopping website implements a proper scheme for } \\
\text { the protection of privacy and personal information protection? }\end{array}$ & $\begin{array}{l}\text { Number } \\
(\%)\end{array}$ \\
\hline Goods and services that require providing detailed personal information & $178(47.6)$ \\
\hline High-priced goods and services & $177(47.3)$ \\
\hline Any goods and services & $115(30.7)$ \\
\hline Goods and services I do not want people to know I purchased & $97(25.9)$ \\
\hline Goods and services that indicate my personal preferences & $74(19.8)$ \\
\hline Goods and services that are indispensable in daily life & $28(7.5)$ \\
\hline Other & $0(0)$ \\
\hline
\end{tabular}

\section{Self-awareness and self-responsibility in terms of misuse of personal information and associated damage}

Finally, we attempted to identify respondents' self-awareness of the possibility of suffering damage due to the misuse of personal information and their recognition of self-responsibility concerning such damage. Q20 asked for a general estimation of the probability of suffering some kind of damage, Q21 asked about the estimated probability of suffering damage themselves, and Q22 asked about the feeling of self-responsibility if personal information is leaked and misused by others and any damage incurred. Table 11 shows the average percentages in the responses to each question.

There was no significant difference between male and female respondents in terms of the estimated probability of their suffering some kind of damage $(t(436)=-1.943, p>.05)$, but there was a statistically significant difference in that more female respondents reported a higher probability of self-responsibility (Q22) than male ones $(t(407.548)=-3.077, p<.01)$. Moreover, there was a statistically significant difference in that respondents estimated a lower probability of their suffering some kind of damage versus the estimate for the public generally $(t(439)=8.548, p<.01)$. That respondents tended to estimate a higher probability of the public's suffering damage than they would themselves, or that they believed in a higher probability of their own safety, as compared to that of the general public, is consistent with their baseless confidence in the protection of privacy for themselves, as discussed in Section 3.1. 
Table 11. Self-awareness of suffering damage as a result of misuse of personal information

\begin{tabular}{|l|c|}
\hline Questions & Average (\%) \\
\hline $\begin{array}{l}\text { Q20: How much do you estimate the probability (\%) of the public suffering some kind } \\
\text { of damage by misuse of their personal information in the current Internet environment? }\end{array}$ & 37.7 \\
\hline $\begin{array}{l}\text { Q21: How much do you estimate the probability (\%) of you suffering some kind of } \\
\text { damage by misuse of your personal information in the current Internet environment? }\end{array}$ & 31.1 \\
\hline $\begin{array}{l}\text { Q22: If you suffer some kind of damage by misuse of your personal information as a } \\
\text { consequence of your online shopping behaviour, to what extent are you responsible for } \\
\text { the damage? Please estimate your responsibility as a percentage. }\end{array}$ & 42.8 \\
\hline
\end{tabular}

\section{Implications of the survey results for B to C e-business companies' trustworthiness and reputation management}

As discussed above, the survey respondents tended to recognise the importance of online privacy policies and the right to privacy, and to believe that companies complied with the online policies. However, many of them did not read online privacy policies frequently, and had optimistic expectations of companies' complying with such policies, without any clear basis for this understanding. Additionally, most of the respondents seemed not to understand the meaning of privacy seals/security icons. Thus, it cannot be said for sure that posting online privacy policies and privacy seals/security icons on online shopping websites is working to engender trust and enhance the reputation of online shopping websites in a proactive manner. Rather, the existing name reputation of online shopping websites, the general reputation of the business organisations operating online shopping websites, and ease of access to reputational information can contribute to engendering a sense of trustworthiness and a better reputation in terms of personal information use and protection.

That is, the halo effect and the Matthew effect (Merton, 1968) can be seen with regard to corporate trustworthiness and reputation for personal information handling with Japanese youngsters. If this halo effect or the Matthew effect is profound, the more business organisations with existing relatively good reputations can develop higher levels of privacy protection schemes, the more they will benefit in terms of a better reputation for privacy protection, and they will be able to collect and use more personal information from consumers. However, existing name values of websites or the businesses operating them do not guarantee that such organisations have high standards of privacy protection. If the online shopping users continue to place disproportionate weight on name reputation as an evaluation standard, it will be more difficult for them to examine the appropriateness of personal information handling by business organisations operating online shopping websites. In fact, it seems that many online shopping users have given up trying to evaluate online shopping websites by assuming that privacy protection schemes are standard in the current situation in which online privacy policies lose substantive differences and a large proportion of online consumers do not understand the meaning of privacy seals/security icons. In this regard, it is important to develop a more understandable standard to evaluate approaches to protecting the right to privacy, and to promote an understanding of the meaning of privacy seals/security icons through industry-wide efforts.

As discussed in Section 3.3, posting high-level online privacy policies or implementing user-friendly online privacy schemes can have a positive impact on the creation of consumer trust and reputation. For example, the survey conducted by Tsai et al. (2011) showed the effectiveness of an indicator that presents the level of privacy protection for the consumers' purchasing behaviours. If online privacy policies and privacy protection schemes of online shopping websites can be designed with the consumers' perspectives in mind, such websites may achieve differentiation of their approaches for privacy protection from others. For example, based on the assumption that a large proportion of consumers do not read the privacy policy thoroughly, an online shopping website that can implement practical functions in terms of privacy protection would have a competitive advantage (e.g. the development of system features that enable users to set their privacy settings in a step-wise fashion and to share such setting information with other online shopping websites). Further examination of the development of user-friendly online privacy protection schemes is necessary. 


\section{Conclusions}

This study examined how Japanese youngsters evaluate the trustworthiness of $\mathrm{B}$ to $\mathrm{C}$ e-business sites in terms of personal information handling by conducting a questionnaire survey and analyses. The survey results show existing good name recognition and/or general reputation of online shopping website and their operators are a most important element in evaluating their trustworthiness, rather than posting online privacy policies and privacy seals/security icons on the websites. On the other hand, it appears that business organisations' approaches to protecting the right to privacy may possibly be recognised as an evaluation standard.

Given the Japanese situation in which the markets of $\mathrm{B}$ to $\mathrm{C}$ e-business are expanding and various kinds of goods and services are available online, it is expected that more personal information will continue to be collected, stored and utilised in business organisations operating online shopping websites. In such situations, the development of user-friendly privacy protection schemes on the basis of a proper understanding of the importance of privacy protection is essential for the growth of fair reputation management in terms of personal information protection.

\section{Acknowledgement}

The authors appreciate the really helpful suggestions for improving this paper provided by Dr Michael Eldred, the guest editor of this issue. This study was supported by the MEXT (Ministry of Education, Culture, Sports, Science and Technology, Japan) Programme for Strategic Research Bases at Private Universities (2012-16) project "Organisational Information Ethics" S1291006, the MEXT Grant-in-Aid for Scientific Research (B) 25285124, and the MEXT Research Grant-in-Aid for Young Scientists (B) 24730320.

\section{References}

Merton, R. K. (1968): The Matthew Effect in Science, Science, 159(3810), 56-63. Available online at http://www.unc.edu/ ffbaum/teaching/PLSC541_Fall06/Merton_Science_1968.pdf (accessed on 11.02.2013).

Murata, K., Orito, Y. and Fukuta, Y. (2013): Japanese Youngsters' Social Attitude towards Online Privacy, forthcoming to Journal of Law, Information and Society.

Next Generation Electronic Commerce Promotion Council of Japan (ECOM) (2008): Survey on Privacy Policy and Other Similar Statements on Websites (in Japanese). Available online at http://www.ecom.jp/report/guideline_20080826.pdf (accessed on 20.06.2009).

Orito, Y., Murata, K., Fukuta, Y., McRobb, S. and Adams, A. A. (2008): Online Privacy and Culture: Evidence from Japan, Proceedings of ETHICOMP 2008, 615-622.

Orito, Y., Kim, E., Fukuta, Y. and Murata, K. (2011): Online Privacy and Culture: A Comparative Study between Japan and Korea, Proceedings of ETHICOMP 2011, 338-346.

Pollach, I. (2007): What's Wrong with Online Privacy Policies? Communications of the ACM, 50 (9), 103-108.

Tsai, J. Y., Egelman, S., Cranor, L., and Acquisti, A. (2011): The Effect of Online Privacy Information on Purchasing Behavior: An Experimental Study, Information Systems Research, 22 (2), 254-268. 


\section{Appendix: Questionnaire Sheet}

\begin{tabular}{|c|c|}
\hline Cover sheet & Q1: Name; Q2: University name; Q3: Gender; Q4: Age \\
\hline \multicolumn{2}{|l|}{ Questions } \\
\hline Q5: Have you bought something on the Web? & $\begin{array}{l}\text { 1.Yes } \\
\text { 2. No } \rightarrow \text { Skip to the Q30 }\end{array}$ \\
\hline $\begin{array}{l}\text { Q6: Have you provided your personal information including your } \\
\text { name, residential address, phone number and credit-card number to } \\
\text { any website? }\end{array}$ & 1. Yes 2. No \\
\hline $\begin{array}{l}\text { Q7: Do you know that almost every online shopping site posts its } \\
\text { online privacy policy? } \\
\text { *An online shopping company usually develops its online privacy pol- } \\
\text { icy or privacy notice and posts it on its website to notify its customers } \\
\text { of the ways of collecting, storing, processing, using and, sharing their } \\
\text { private information. }\end{array}$ & $\begin{array}{l}\text { 1. Yes } \\
\text { 2. No } \rightarrow \text { Skip to the Q14 }\end{array}$ \\
\hline Q8: Is a privacy policy an important element for your online shopping? & $\begin{array}{ll}\text { 1. Very important } & \text { 2. Important } \\
\text { 3. Not so important } & \text { 4. Not important at all } \\
\end{array}$ \\
\hline $\begin{array}{l}\text { Q9: Do you read a privacy policy when you purchase something } \\
\text { online? }\end{array}$ & $\begin{array}{ll}\text { 1. I read them frequently } & \text { 2. I read them occasionally } \\
\text { 3. I seldom read them } & 4 \text {. I have not read them at all }\end{array}$ \\
\hline $\begin{array}{l}\text { Q10: Have you worried about whether online shopping companies } \\
\text { abide by their online privacy policies or not? }\end{array}$ & $\begin{array}{l}\text { 1. I usually worry about this } \\
\text { 2. I sometimes worry about this } \\
\text { 3. I rarely worry about this } \\
\text { 4. I have not worried about this at all }\end{array}$ \\
\hline $\begin{array}{l}\text { Q11: Do you believe that companies comply with their privacy poli- } \\
\text { cies? }\end{array}$ & $\begin{array}{ll}\text { 1. Every company does } & \text { 2. Many companies do } \\
\text { 3. A small number of companies do } & \text { 4. Few companies do } \\
\end{array}$ \\
\hline $\begin{array}{l}\text { Q12: If you purchase products or services online that are similar in } \\
\text { price, would you prefer to purchase them on a website that provides } \\
\text { a highly advanced online privacy policy (e.g. including understandable } \\
\text { sentences, using icons and pictures) as opposed to a website that } \\
\text { provides a lower level online privacy policy? }\end{array}$ & $\begin{array}{ll}\text { 1.Yes, I'd like to, very much } & \text { 2. Yes, if anything } \\
\text { 3. I'm not quite sure on that point } & \text { 4. No, I would not }\end{array}$ \\
\hline $\begin{array}{l}\text { Q13: If you purchase something online, under what circumstances is } \\
\text { it to be noted whether the online shopping website implements a } \\
\text { proper scheme for the protection of privacy and personal information } \\
\text { protection? (Multiple answers allowed) }\end{array}$ & $\begin{array}{l}\text { 1. When I purchase goods and services that indicate my personal } \\
\text { preferences, e.g. books, online magazines } \\
\text { 2. When I purchase goods and services I do not want people to } \\
\text { know purchased, such as beauty products } \\
\text { 3. When I purchase high-priced goods and services } \\
\text { 4. When I purchase goods and services that require providing } \\
\text { detailed personal information, such as with a matrimonial } \\
\text { agency } \\
\text { 5.When I purchase goods and services that are indispensable in } \\
\text { daily life } \\
\text { 6. Any goods and services } \\
\text { 7. Other [ ] }\end{array}$ \\
\hline Q14: Is the protection of the right to privacy important? & $\begin{array}{ll}\text { 1. Very important } & \text { 2. Important } \\
\text { 3. Not so important } & \text { 4. Not important } \\
\end{array}$ \\
\hline Q15: Do you know what the right to privacy is? & $\begin{array}{l}\text { 1. Yes, I know } \\
\text { 2. No, I don't know } \rightarrow \text { Skip to Q18 }\end{array}$ \\
\hline Q16: Please describe what the right to privacy is. & {[} \\
\hline Q17: Please describe why the right to privacy is important. & {[} \\
\hline $\begin{array}{l}\text { Q18: What characteristics does a website have to which you don't } \\
\text { want to provide your personal information? (Multiple answers allo- } \\
\text { wed) }\end{array}$ & $\begin{array}{l}\text { 1. Websites that have a low profile or are operated by low-profile } \\
\text { companies (e.g. unofficial websites, websites operated by an } \\
\text { individual, overseas websites) } \\
\text { 2. Websites that can be accessed by the general public online } \\
\text { (e.g. social networking services websites, online community } \\
\text { websites) } \\
\text { 3. Websites with untrustworthy reputations (e.g. websites oper- } \\
\text { ated by an organisation that had leaked personal information) } \\
\text { 4. Websites that have suspect designs and too many advertise- } \\
\text { ments } \\
\text { 5. Websites that provide suspect goods and services } \\
\text { 6. Websites I do not want people to know I access (e.g. adult } \\
\text { sites) } \\
\text { 7. Websites that require a money transaction (e.g. auction web- } \\
\text { sites, online shopping websites) }\end{array}$ \\
\hline
\end{tabular}


Q19: What characteristics does a website have to which you feel safe providing your personal information? (Multiple answers allowed)
8. Websites that seem to fail to show well-organised privacy policies, personal information protection schemes, and security

9. Websites that require too much personal information

10. Websites that provide free services

11. Any website

12. I have no idea

13. Other [

1. Websites with a high profile and high traffic, or having many users (e.g. official websites, websites operated by a large organisation, and public organisations)

2. Websites whose reputation information provided by a third party is accessible

3. Websites that seem to have well-organised privacy policies and personal information protection schemes

4. Websites that seem to maintain technological security

5. Websites that I and/or my friends have used

6. Online shopping websites and auction websites

7. Websites that have restricted access (e.g. member-only websites)

8. Websites operated by my acquaintances

9. Websites that allow users to communicate directly with operators of the websites

10. Recruiting websites

11. Websites that have a preferable web design

12. Nothing

13. I have no idea

14. Other

Q20: How much do you estimate the probability (\%) of the public suffering some kind of damage by misuse of their personal information in the current Internet environment?

Q21: How much do you estimate the probability (\%) of you suffering some kind of damage by misuse of your personal information in the current Internet environment?

Q22: If you suffer some kind of damage by misuse of your personal information as a consequence of your online shopping behaviour, to what extent are you responsible for the damage? Please estimate $y$ our responsibility as a percentage.

Q23: Do you understand that your personal information is encrypted when you submit your personal information through an online shopping website?

Q24: Do you understand the meaning of the padlock icon often shown on your browser when you visit online shopping sites?

Q25:Do you recognise the following seal/icon?

1. Yes, I understand this icon
2. I have seen this icon, but I don't know what it represents

3. I don't know this icon at all

1. Yes, I know what this seal/icon represents

2. I have seen this seal/icon, but I don't know what it represents

3. I don't know this seal/icon at all

Q26:Do you recognise the following seal/icon?

TRUSTe

1. Yes, I know what this seal/icon represents

2. I have seen this seal/icon, but I don't know what it represents

3. I don't know this seal/icon at all
Q27:Do you recognise the following seal/icon?

\section{(C) thautee}

1. Yes, I know what this seal/icon represents

2. I have seen this seal/icon, but I don't know what it represents

3. I don't know this seal/icon at all 


\begin{tabular}{|l|l|}
\hline Q28: Do you recognise the following seal/icon? & $\begin{array}{l}\text { 1. Yes, I know what this seal/icon represents } \\
\text { 2. I have seen this seal/icon, but I don't know what it represents } \\
\text { 3. I don't know this seal/icon at all }\end{array}$ \\
\hline Q29: Do you recognise the following seal/icon? & $\begin{array}{l}\text { 1. Yes, I know what this seal/icon represents } \\
\text { 2. I have seen this seal/icon, but I don't know what it represents } \\
\text { 3. I don't know this seal/icon at all }\end{array}$ \\
\hline $\begin{array}{l}\text { Q30: Thank you for your cooperation with our questionnaire. If you } \\
\text { registered your name or your student number first, and you can be } \\
\text { available for an interview, please let us know. }\end{array}$ & $\begin{array}{l}\text { 1. Yes, I can be contacted about an interview } \\
\text { 2. No. I can't }\end{array}$ \\
\hline
\end{tabular}

